\title{
PERLINDUNGAN HUKUM BAGI DEBITUR ATAS KELALAIAN KREDITUR MELAKUKAN ROYA JAMINAN FIDUSIA
}

\author{
Desy Sukariyanti \\ Magister Kenotariatan, Fakultas Hukum, Universitas Surabaya \\ E-mail : desy.jurnal2019@gmail.com \\ Daniel Djoko Tarliman \\ Magister Kenotariatan, Fakultas Hukum, Universitas Surabaya
}

\begin{abstract}
ABSTRAK
Pendaftaran jaminan fidusia meliputi pula kewajiban bagi kreditur untuk memberitahukan kepada kantor pendaftaran fidusia pada saat hutang pokok yang dijamin dengan fidusia telah lunas untuk selanjutnya dilakukan pencoretan atau biasa dikenal dengan istilah roya. Adanya kelalaian dari kreditur dalam melakukan roya atas jaminan fidusia dapat mengakibatkan debitur dirugikan karena obyek jaminan yang semsetinya hapus bersamaan dengan lunasnya hutang pokok tidak dapat dijaminkan lagi. Penulis dalam penelitian ini ingin menelaah dan menganalisa lebih lanjut tentang perlindungan hukum bagi debitur saat kreditur tidak melakukan roya atas jaminan fidusia yang telah lunas dan bentuk tanggung gugat kreditur atas kelalaian melakukan roya pada jaminan fidusia yang telah lunas. Metode penelitian yang digunakan adalah penelitian hukum normatif. Hasil penelitian menunjukkan bahwa Undang-Undang Jaminan Fidusia telah memberikan perlindungan hukum kepada debitur atas hutang yang telah lunas dengan mewajibkan kreditur untuk melakukan pencoretan jaminan fidusia. Kreditur yang lalai dalam melakukan pencoretan pencatatan Jaminan Fidusia dapat dikualifikasikan melakukan perbuatan melawan hukum dan bertanggung gugat untuk mengganti kerugian yang dialami oleh debitur.
\end{abstract}

Kata Kunci : Jaminan Fidusia, Roya, Perlindungan Hukum

\section{ABSTRACT}

Fiduciary registration includes the obligation for creditors to notify the fiduciary registration office when the principal debt guaranteed by the fiduciary has been repaid for subsequent write-offs or commonly known as roya. The negligence of the creditor in conducting a transaction on fiduciary collateral can result in the debtor being harmed because the object of collateral which is as clear as the same as the repayment of the principal debt cannot be guaranteed anymore. The author in this study wants to examine and analyze further about legal protection for debtors when creditors do not carry out the payment of fiduciary guarantees that have been paid off and the form of creditor liability for negligence in carrying out a transaction on fiduciary guarantees that have been paid off. The research method used is normative legal research. The results of the study indicate that the Fiduciary Guarantee Law has provided legal protection to debtors for debts that have been paid off by requiring creditors to write off fiduciary collateral. Creditors who are negligent in writing down the recording of Fiduciary Guarantees can be qualified to commit acts against the law and are liable to compensate for the losses experienced by the debtor.

Keywords: Fiduciary Guarantee, Dropoff, Legal Protection 


\section{Pendahuluan}

Jaminan mempunyai fungsi yang sangat penting dalam kegiatan ekonomi pada umumnya karena dalam pemberian pinjaman modal dari lembaga keuangan (baik bank maupun bukan bank) mensyaratkan adanya suatu jaminan, yang harus dipenuhi para pencari modal kalau ia ingin mendapatkan pinjaman/tambahan modal (berupa kredit) tersebut baik untuk jangka panjang maupun jangka pendek. Bagi pihak debitur bentuk jaminan yang baik adalah bentuk jaminan yang tidak akan melumpuhkan kegiatan usahanya sehari-hari, sedangkan bagi kreditur jaminan yang baik adalah jaminan yang dapat memberikan rasa aman dan kepastian hukum bahwa kredit yang diberikan dapat diperoleh kembali tepat pada waktunya.

Dalam setiap perjanjian yang bernuansa hutang piutang, kemungkinan terjadi wanprestasi adalah sangat besar. Wanprestasi dapat disebabkan oleh berbagai faktor, misalnya karena usaha yang dirintis oleh debitur mengalami kemacetan, kerugian, ataupun penipuan, dapat juga karena keadaan memaksa atau overmacht, atau mungkin saja karena kepribadian dari debiturnya sendiri yang tidak memiliki itikad baik dalam berkredit. Wanprestasi disini adalah keadaan dimana debitur tidak melaksanakan kewajibannya yaitu membayar bunga dari kreditnya ataupun sama sekali tidak mau melunasi hutangnya. (J. Satrio, 2012:4).

Pada jaminan kebendaan selalu diikuti dengan adanya pencatatan dan publikasi sebagai pemenuhan asas publisitas. Pencatatan dan publikasi pada hukum kebendaan pelaksanaannya diserahkan sepenuhnya pada kehendak para pihak yang melangsungkan perbuatan hukumnya. Publikasi ini karena memang ditujukan untuk melindungi kepentingan pihak ketiga adalah terbuka untuk umum. Tidak dilakukannya pencatatan dan publikasi, berakibat tidak berlakunya perbuatan hukum yang dikehendaki oleh para pihak terhadap pihak ketiga, berarti bahwa apabila pencatatan dan publikasi tersebut diabaikan, para pihak tidak dapat mendalilkan hubungan hukum yang ada di antara para pihak terhadap pihak ketiga. (Ida Ayu Made Widyari, 2012:26)

Kewajiban pencatatan dan publikasi atas suatu perjanjian penjaminan yang merupakan perjanjian assesoir dari suatu perjanjian pokok yang bersifat perorangan lahirlah suatu hak kebendaan yang bersifat droit de suite dan droit de preference. Pemegang hak atas jaminan kebendaan yang dijaminkan secara kebendaan tersebut yaitu hak yang melekat atas kebendaan yang dijaminkan kemanapun kebendaan tersebut dialihkan.(Herlien Budiono, 2008:230).

UU Jaminan Fidusia mengatur tentang kewajiban pendaftaran jaminan fidusia agar memberikan kepastian hukum kepada para pihak yang berkepentingan dan pendaftaran jaminan fidusia ini memberikan hak yang didahulukan (preference) kepada penerima fidusia terhadap kreditor lain. Benda yang menjadi obyek jaminan Fidusia adalah benda bergerak baik yang berwujud maupun yang tidak berwujud dan benda tidak bergerak khususnya bangunan yang tidak dapat 
dibebani hak tanggungan. Benda yang dijadikan jaminan fidusia tetap berada dalam penguasaan Pemberi Fidusia, sebagai agunan bagi pelunasan utang tertentu, yang memberikan kedudukan yang diutamakan kepada Penerima Fidusia terhadap kreditor lainnya. Berlakunya Undang-Undang Jaminan Fidusia di Indonesia secara langsung telah memberikan rasa aman khusunya bagi kreditur dalam kaitannya dengan perjanjian hutang piutang.

Pendaftaran jaminan fidusia diatur pada Pasal 11 UU Jaminan Fidusia yang menyatakan: “(1) Benda yang dibebani dengan jaminan fidusia wajib didaftarkan.; (2) Dalam hal benda yang dibebani dengan Jaminan Fidusia berada di luar wilayah negara Republik Indonesia, kewajiban sebagaimana dimaksud dalam ayat (1) tetap berlaku". Pendaftaran jaminan fidusia meliputi pula kewajiban bagi kreditur untuk memberitahukan kepada kantor pendaftaran fidusia pada saat hutang pokok yang dijamin dengan fidusia telah lunas untuk selanjutnya dilakukan pencoretan atau biasa dikenal dengan istilah roya. Adanya kelalaian dari kreditur dalam melakukan roya atas jaminan fidusia dapat mengakibatkan debitur dirugikan karena obyek jaminan yang semsetinya hapus bersamaan dengan lunasnya hutang pokok tidak dapat dijaminkan lagi.

\section{Rumusan Masalah}

1) Apa bentuk perlindungan hukum bagi debitur saat kreditur tidak melakukan roya atas jaminan fidusia yang telah lunas?
2) Apa bentuk tanggung gugat kreditur atas kelalaian melakukan roya pada jaminan fidusia yang telah lunas?

\section{Metode Penelitian}

Metode yang digunakan dalam penelitian ini adalah metode penelitian yuridis normatif yang menekankan pada norma-norma hukum dengan menganalisa peraturan perundang-undangan terkait. Dalam Penelitian ini peneliti menggunakan dua metode pendekatan masalah yaitu : 1) Statute Approach, pendekatan dengan menelaah semua peraturan perundang-undangan yang bersangkut paut dengan permasalahan (isu hukum) yang sedang dihadapi. 2) Conseptual Approach, yaitu pendekatan yang beranjak dari pandanganpandangan dan doktrin-doktrin yang berkembang di dalam ilmu hukum. (Peter Mahmud Marzuki, 2010:95-97).

\section{Pembahasan}

\section{Perlindungan Hukum Bagi Debitur Saat Kreditur Tidak Melakukan Roya Atas Jaminan Fidusia Yang Telah Lunas}

Hakekatnya setiap orang berhak mendapatkan perlindungan dari hukum. Hampir seluruh hubungan hukum harus mendapat perlindungan dari hukum. Perlindungan hukum harus melihat tahapan yakni perlindungan hukum lahir dari suatu ketentuan hukum dan segala peraturan hukum yang diberikan oleh masyarakat yang pada dasarnya merupakan kesepakatan masyarakat tersebut untuk mengatur hubungan prilaku 
antara anggota-anggota masyarakat dan antara perseoranan dengan pemerintah yang dianggap mewakili kepentingan masyarakat.

Awal mula lahirnya teori perlindungan hukum bersumber dari teori hukum alam atau aliran hukum alam yang dikemukakan oleh Plato, Aristoteles yang menjelaskan bahwa hukum itu bersumber dari Tuhan yang bersifat universal dan abadi, serta antara hukum dan moral tidak boleh dipisahkan. Secara umum Plato dan Aristoteles memandang hukum dan moral adalah cerminan kehidupan manusia yang diwujudkan melalui hukum dan moral.(Satjipto Rahardjo,2002:52). Sedangkan Thomas Aquinas mengemukakan bahwa hukum alam adalah ketentuan akal yang bersumber dari Tuhan bertujuan untuk kebaikan dan dibuat oleh orang yang mengurus masyarakat untuk disebarluaskan. (Ibid)

Secara lebih luas Thomas Aquinas mengatakan bahwa hukum alam adalah cerminan dari undangundang abadi (lex naturalis), hukum alam tidak hanya disajikan sebagai ilmu pengetahuan, tetapi juga diterima sebagai prinsip-prinsip dasar dalam perundang-undangan. Hukum alam telah menunjukkan bahwa sesungguhnya hakekat kebenaran dan keadilan merupakan suatu konsep yang mencakup banyak teori. Subtansi hukum alam telah menempatkan suatu asas yang bersifat universal yang bisa disebut sebagai hak asasi manusia (HAM).

Perlindungan hukum dapat berarti perlindungan yang diberikan hukum terhadap sesuatu. Hukum sejatinya harus dapat memberikan perlindungan terhadap semua pihak sesuai dengan status hukumnya karena setiap orang memiliki kedudukan yang sama dihadapan hukum. Setiap aparat penegak hukum wajib menegakkan hukum dan dengan berfungsinya aturan hukum, maka secara tidak langsung pula hukum akan memberikan perlindungan terhadap setiap hubungan hukum atau segala aspek dalam kehidupan masyarakat yang diatur oleh hukum itu sendiri.

Menurut

Sudikno

Mertokusumo, yang dimaksud dengan hukum adalah kumpulan peraturan atau kaedah yang mempunyai isi yang bersifat umum dan normatif, umum karena berlaku bagi setiap orang dan normative karena menentukan apa yang seyogyanya dilakukan, apa yang tidak boleh dilakukan atau harus dilakukan serta menentukan bagaimana caranya melaksanakan kepatuhan pada kaedah-kaedah. (Sudikno Merokusumo, 1991:38). Jadi perlindungan hukum adalah suatu perbuatan hal melindungi subjek - subjek hukum dengan peraturan perundang-undangan yang berlaku dan pelaksanaannya dapat dipaksakan dengan suatu sanksi. Sedangkan menurut Philipus M. Hadjon bahwa Perlindungan Hukum bagi rakyat sebagai tindakan pemerintah yang bersifat preventif dan represif. Perlindungan hukum yang bersifat preventif bertujuan untuk mencegah terjadinya sengketa yang mengarahkan tindakan pemerintah bersifat represif bertujuan untuk menyelesaikan terjadinya sengketa termasuk penanganan di lembaga 
peradilan. (Philipus M. Hadjon, 2002:31)

Dalam lembaga penjaminan dikenal lembaga fidusia. Asal usul dari kata fidusia adalah fides yang berarti "kepercayaan". Itulah sebabnya pengertian Fidusiaire Eigendomsoverdracht sering dikaitkan dengan pengertian penyerahan jaminan hak milik berdasarkan kepercayaan. Dikaitkan dengan hubungan yang terbentuk antara debitur dan kreditur, azas kepercayaan ini bersifat sentral oleh karena pemberi fidusia (debitur) percaya bahwa penerima fidusia (kreditur) akan mengembalikan hak milik yang telah diserahkan setelah pemberi fidusia membayar lunas utangnya. Sedangkan pihak kreditur juga percaya bahwa debitur akan menjaga barang jaminan yang berada dalam kekuasaannya (Firdaus, 1999:11).

Jaminan fidusia merupakan suatu jaminan kebendaan yang dikenal dalam hukum positif, yang dapat memberikan keuntungan secara ekonomis kepada pelaku usaha bisnis jika dibandingkan dengan lembaga jaminan lainnya. Keuntungan ini dapat dilihat dari adanya penguasaan terhadap benda jaminan sehingga usaha yang sedang dijalankan tetap bisa berjalan dan pinjaman kredit tersebut dapat dikembalikan dengan lancar. Fiducia Eigendom Overdracht (FEO), yang untuk selanjutnya disebut fidusia, merupakan pengalihan hak kepemilikan atas suatu benda dengan dasar kepercayaan dan dengan ketentuan bahwa benda yang hak kepemilikannya dialihkan itu tetap dalam penguasaan si pemilik benda. Tetapi penyerahan hak milik atas benda jaminan fidusia tidaklah sempurna seperti pengalihan hak milik dalam jual beli, karena pengalihan hak hanya secara constitutum prossesorium, artinya secara yuridis hanya hak kepemilikannya saja yang dialihkan sedangkan barangnya tetap berada dalam kekuasaan pemberi fidusia. (Ahmad Sanusi, 2013:6)

Persoalan yang terakhir ini menjadi berharga untuk diperhatikan karena konstruksi fidusia memang memiliki ciri yang khas: penyerahan kepada kreditur hanya berupa hak miliknya, sedangkan barang tetap berada di dalam penguasaan debitur. Inilah yang disebut sebagai constitutum possessorium. Namun demikian perlu dimengerti bahwa dalam hal jaminan fidusia, pengalihan hak kepemilikan semata-mata sebagai jaminan bagi pelunasan hutang bukan untuk seterusnya dimiliki oleh penerima fidusia. Inilah yang disebut sebagai constitutum possessorium.

Sejalan dengan prinsip memberikan kepastian hukum, maka Undang- Undang Jaminan Fidusia mengambil prinsip pendaftaran jaminan fidusia.Pendaftaran tersebut diharapkan memberikan kepastian hukum kepada pemberi dan penerima fidusia maupun kepada pihak ketiga.Pendaftaran jaminan fidusia dilakukan pada Kementrian Hukum dan Hak Asasi Manusia RI. Perlindungan hukum dan kepentingan kreditor dalam UUJF dapat dilihat pada Pasal 20 UUJF:"Fidusia tetap mengikuti Benda yang menjadi objek Jaminan fidusia 
dalam tangan siapapun Benda tersebut berada, kecuali pengalihan atas benda persediaan yang menjadi objek Jaminan Fidusia".35 Sebagai hak kebendaaan, maka jaminan fidusia menyandang asas-asas antara lain hak jaminan itu mengikuti bendanya (droit de suit), mempunyai kedudukan utama (hak preferen) dalam kaitannya dengan adanya kreditor lainnya.

Pembebanan fidusia diatur dalam Pasal 4 sampai Pasal 10 Undang-Undang Nomor 42 Tahun 1999 tentang Jaminan Fidusia, yang dapat dilakukan dengan menggunakan instrumen yang disebut dengan "Akta Jaminan Fidusia". Akta jaminan fidusia ini dibuat dalam bentuk akta otentik, dibuat dihadapan Notaris dengan penggunaaan bahasa Indonesia. Menurut pasal 6 Undang-Undang Jaminan Fidusia, akta tersebut yang dimaksud antara lain harus berisikan hal-hal:

1. Identitas pihak pemberi dan penerima fidusia

2. Data perjanjian pokok yang dijamin fidusia

3. Uraian tentang benda yang menjadi objek jaminan fidusia

4. Nilai penjaminan dan

5. Nilai benda yang menjadi objek jaminan fidusia

Seperti bentuk-bentuk jaminan lainnya, fidusia juga tidak terbebas dari sifat accessoir, karena memang fidusia ini wajib mengikuti perjanjian induknya yang telah ada antara debitur dan kreditur (Perjanjian Kredit). Dalam praktek perbankan, lembaga fidusia ini sudah dikenal luas dan bahkan dipandang sebagai kebutuhan riil untuk mendukung mekanisme pergerakan usaha yang membutuhkan kredit dengan jaminan benda bergerak. Lembaga fidusia ini juga sudah diakui oleh yurisprudensi, meskipun perjanjian fidusia tidak dikenal dalam KUHPerdata. Makanya, bentuk perjanjian ini sering disebut sebagai innominat atau onbenoemde overeenkomst. Tentu saja, status seperti itu sama sekali tidak melepaskan fidusia dari ketentuanketentuan umum tentang perikatan seperti yang dirumuskan oleh Bab IIV Buku III KUHPerdata.

Sistem

administrasi pendaftaran jaminan fidusia berupa prosedur pendaftaran jaminan fidusia serta penerbitan sertifikat jaminan fidusia yang dapat dilakukan secara online oleh pemohon pendaftaran jaminan fidusia melalui sistem elektronik milik Direktorat Jendral Administrasi Hukum Umum (Ditjen AHU). Sumber hukum yang menjadi dasar pembentukkan dan pemberlakuan sistem ini adalah Peraturan Pemerintan Nomor 21 Tahun 2015 Tentang Tata Cara Pendaftaran Jaminan Fidusia Dan Biaya Pembuatan Akta Jaminan Fidusia (selanjutnya ditulis PP No. 21 Th. 2015).

Menurut Pasal 25 ayat (1) UU Jaminan Fidusia apabila terjadi halhal tertentu, maka Jaminan fidusia demi hukum dianggap telah hapus, kejadian-kejadian tersebut adalah:

1. Hapusnya hutang yang dijamin oleh jaminan fidusia.

2. Pelepasan hak atas Jaminan fidusia oleh penerima fidusia.

3. Musnahnya benda yang menjadi jaminan fidusia.

Hapusnya jaminan fidusia karena lunasnya hutang yang 
dijamin dengan jaminan fidusia adalah konsekuensi logis dari karakter perjanjian assessoir. Jadi, jika perjanjian hutang piutangnya tersebut hapus karena sebab apapun maka jaminan fidusia tersebut menjadi hapus pula. Sementara itu hapusnya jaminan fidusia karena pelepasan hak atas jaminan Fidusia oleh penerima jaminan fidusia adalah wajar karena sebagai pihak yang mempunyai hak dia bebas untuk mempertahankan atau melepaskan haknya tersebut.

Hapusnya jaminan fidusia karena musnahnya barang jaminan fidusia tersebut dapat dibenarkan karena tidak ada manfaat lagi fidusia itu dipertahankan, jika barang objek jaminan fidusia tersebut sudah tidak ada akan tetapi jika ada asuransi maka hal tersebut menjadi hak dari penerima fidusia dan pemberi fidusia tersebut harus membuktikan bahwa musnahnya barang yang menjadi objek jaminan fidusia tersebut adalah diluar dari kesalahannya.(Munir Fuady, 2000:50)

Prosedur yang harus ditempuh jika jaminan fidusia tersebut hapus, yakni dengan melakukan pencoretan (Roya) pencatatan jaminan fidusia tersebut di kantor pendaftaran fidusia. Selanjutnya kantor pendaftaran fidusia menerbitkan surat keterangan yang menyatakan bahwa sertifikat jaminan fidusia tersebut tidak berlaku lagi dan dalam hal ini dilakukan pencoretan jaminan fidusia tersebut dari buku daftar fidusia yang ada pada kantor pendaftaran fidusia.

Sesuai dengan sifat accesoir dari jaminan fidusia yang berakhirnya mengikuti perjanjian pokok, maka dengan adanya pelunasan dari debitur yang membuat terpenuhinya segala kewajiban dari debitur akan mengakibatkan perjanjian pokok antara debitur dengan kreditur berakhir, sehingga dengan demikian maka perjanjian tambahan yaitu jaminan fidusia juga berakhir pula.(Hatta Isnaini Wahyu Utomo, 2017:7). Namun dengan adanya kewajiban administratif untuk melakukan pencoretan jaminan fidusia maka adanya pelunasan dari debitur belum sepenuhnya mengakhiri jaminan fidusia.

Adanya

pencoretan pencatatan jaminan fidusia menjadi hak dari debitur setelah memenuhi kewajiban membayar hutangnya kepada kreditur. Disebutkan dalam Pasal 25 ayat (3) UU Jaminan Fidusia bahwa atas hapusnya jaminan fidusia penerima fidusia memberitahukan kepada Kantor Pendaftaran Fidusia mengenai hapusnya jaminan fidusia dengan melampirkan pernyataan mengenai hapusnya utang. Merujuk pada Pasal 1 angka 6 UU Jaminan Fidusia yang menyatakan bahwa penerima fidusia adalah perseorangan atau korporasi yang mempunyai piutang yang pembayarannya dijamin dengan jaminan fidusia. Maka kewajiban untuk melakukan pencoretan pencatatan jaminan fidusia adalah menjadi kewajiban dari Kreditur.

Tanggung Gugat Kreditur Atas Kelalaian Melakukan Roya Pada Jaminan Fidusia Yang Telah Lunas

Adanya kewajiban mendaftarkan jaminan fidusia pada 
Kementrian Hukum dan Hak Asasi Manusia, menunjukan adanya asas publisitas.Dalam pendaftaran tersebut memuat data yang lengkap yang dicantumkan dalam akta jaminan fidusia. Pendaftaran tersebut dimaksudkan agar khalayak ramai, yang mempunyai kepentingan (pihak ketiga) bisa mengetahuinya, terutama bebanbeban yang menindih benda tertentu, dan oleh karena itu daftar yang bersangkutan dinyatakan terbuka untuk umum (Pasal 18 UUJF), dan ketentuan pendaftaran ini diadakan agar dapat diketahui oleh pihak ketiga bahwa suatu barang sudah dijaminkan secara fidusia, sehingga pihak ketiga yang akan menerima pengalihan hak, berpikir kembali untuk menerima pengalihan hak tersebut serta mempunyai akibat hukum terhadap pihak ketiga yang menerima pengalihan tersebut.(Farah Diana, dkk., 2017:40)

Hal ini tentunya tidak menimbulkan masalah apabila hanya terdapat satu kreditor yang mempunyai piutang atas diri kreditor, dimana debitor tersebut akan memperoleh pelunasan dari semua harta. Dalam hal demikian maka kreditor konkuren tidak memperoleh perindungan hukum.Oleh karena itu agar semua pihak mendapatkan perlindungan hukum benda debitor tanpa harus bersaing dengan kreditor lainnya.Keadaan yang demikian tentunya telah cukup memberikan perlindungan bagi kreditor dalam pelunasan piutangnya apabila debitor wanprestasi.

Jaminan Fidusia lahir pada tanggal yang sama dengan tanggal
Jaminan Fidusia dicatat. Begitu juga halnya dengan Sertifikat Jaminan Fidusia, dapat dicetak pada tanggal yang sama dengan tanggal Jaminan Fidusia dicatat. Peraturan Pemerintah republik Indonesia Nomor 21 Tahun 2015 tentang Tata Cara Pendaftaran Jaminan Fidusia dan Biaya Pembuatan Akta Jaminan Fidusia dalam Pasal 16 menyebutkan bahwa apabila jaminan fidusia telah hapus, maka Penerima Fidusia, kuasa atau wakilnya, wajib memberitahukan kepada Menteri dalam jangka waktu paling lama 14 (empat belas) hari terhitung sejak tanggal hapusnya Jaminan Fidusia. Pemberitahuan penghapusan Jaminan Fidusia tersebut paling sedikit memuat:

1) Keterangan atau alasan hapusnya Jaminan Fidusia;

2) Nomor dan tanggal sertifikat Jaminan Fidusia;

3) Nama dan tempat kedudukan notaris; dan

4) Tanggal hapusnya Jaminan Fidusia.

Berdasarkan pemberitahuan penghapusan jaminan fidusia tersebut, jaminan fidusia dihapus dari daftar jaminan fidusia dan diterbitkan keterangan penghapusan yang menyatakan sertifikat jaminan fidusia yang bersangkutan tidak berlaku lagi. Apabila penerima fidusia, kuasa atau wakilnya tidak memberitahukan penghapusan jaminan fidusia, maka jaminan fidusia yang bersangkutan tidak dapat didaftarkan kembali.

Suatu permasalahan yang dapat terjadi adalah ketika suatu benda jaminan fidusia yang telah 
didaftarkan di Kementrian Hukum dan Hak Asasi Manusia (Kemenkuham), namun setelah berakhirnya hutang pokok kreditur tidak melakukan pencoretan terhadap obyek jaminan fidusia yang telah lunas tersebut. Penghapusan jaminan fidusia tentu saja sangat erat hubungannya dengan perlindungan dan kepastian hukum bagi debitor selaku pemberi fidusia. Dengan berakhirnya perjanjian pokok sebagai perjanjian induk dari jaminan fidusia memang membuat perjanjian jaminan fidusia ikut berakhir, namun tidak cukup hanya berakhir saja. Debitor butuh kepastian akan berakhirnya jaminan fidusia tersebut dengan dilakukannya penghapusan jaminan fidusia.

Aturan hukum mengenai jaminan fidusia mewajibkan kepada kreditor selaku penerima fidusia untuk melakukan penghapusan jaminan fidusia. Namun yang sangat disayangkan dalam aturan hukum tentang Jaminan Fidusia, baik itu Undang-Undang Jaminan Fidusia; Peraturan tentang Pendaftaran Jaminan Fidusia terhadap pembiayaan kendaraan bermotor; dan Peraturan tentang Tata Cara Pendaftaran Jaminan Fidusia secara Elektronik, kesemuanya tidak memuat sanksi bagi Perusahaan Pembiayaan atau secara umum kreditor sebagi penerima yang tidak melakukan penghapusan jaminan fidusia.

Mengenai tidak adanya pengaturan tentang sanksi terhadap jaminan fidusia yang tidak dilakukan penghapusan merupakan kelemahan dari peraturan mengenai jaminan fidusia itu sendiri. Hal ini menunjukkan bahwa di sini terdapat kelemahan terhadap perlindungan hukum bagi kreditor/pemberi fidusia yang seharusnya pada tahapan inilah si debitor dilindungi. Apabila perjanjian pokok telah berakhir, maka kreditor/penerima fidusia urusannya telah selesai sementara bagi debitor, penghapusan jaminan fidusia perlu dilakukan untuk menjamin haknya. Debitor tidak dapat menjaminkan bendanya kembali karena tidak boleh adanya fidusia ulang. Obyek yang sama tidak dapat dijaminkan kembali kepada kreditor lainnya karena status hukum kreditor yang pertama masih melekat pada benda tersebut. Apabila masih melekat hak jaminan atas benda tersebut, maka debitor tidak dapat mengalihkan dan menjual benda tersebut. Dengan tidak adanya sanksi yang tegas, maka perlindungan hukum terhadap debitor jadi terabaikan

Suatu aturan hukum yang tidak dibarengi dengan adanya sanksi menjadikan perlindungan hukum sangat lemah.Kelemahan pada aturan hukum mengenai jaminan fidusia terlihat dari sanksi yang diberikan kepada pihak yang tidak melakukan pendaftaran jaminan fidusia saja. Untuk penghapusan jaminan fidusia, aturan-aturan hukum tersebut sama sekali tidak memberi pengaturan yang jelas sehingga atas kelalaian dari kreditur dalam melakukan roya atas jaminan fidusia yang telah lunas hanya dapat dilakukan gugatan atas dasar perbuatan melanggar hukum.

Akibat kelalaian yang dilakukan oleh kreditur pihak yang 
dirugikan dapat menuntut ganti kerugian kepada notaris, apabila memenuhi unsur-unsur sebagai berikut:

1. Adanya suatu perbuatan, yaitu suatu perbuatan melawan hukum selalu diawali oleh suatu perbuatan dari si pelakunya.

2. Perbuatan tersebut melawan hukum, yaitu unsur melawan hukum ini diartikan dalam arti seluas-luasnya, yakni meliputi hal-hal sebagai berikut:

a. perbuatan yang melanggar undang-undang yang berlaku,

b. yang melanggar hak orang lain yang dijamin oleh hukum,

c. perbuatan yang bertentangan dengan kewajiban hukum si pelaku,

d. perbuatan yang bertentangan dengan kesusilaan,

e. dengan kehati-hatian atau keharusan dalam pergaulan masyarakat yang baik.

3. Adanya kesalahan dari pihak pelaku, yaitu suatu tindakan dianggap oleh hukum mengandung unsur kesalahan jika memenuhi unsur-unsur sebagai berikut:

a. ada unsur kesengajaan,

b. ada unsur kelalaian,

c. tidak ada alasan pembenar atau alasan pemaaf, seperti keadaan memaksa (overmacht), membela diri, tidak waras, dan lain-lain.

4. Adanya kerugian bagi korban, yaitu kerugian karena perbuatan melawan hukum meliputi kerugian materiil dan immaterial, yang juga dinilai dengan uang.

5. Adanya hubungan kausalitas, yaitu hubungan sebab akibat yang dengan adanya perbuatan yang dilakukan seseorang dapat mengakibatkan pihak lain menderita kerugian. Ada 2 (dua) teori, yaitu:

a. Conditio Sine Qua Non.

Menurut teori ini, setiap orang yang melakukan perbuatan me-langgar hukum selalu bertanggung gugat, jika perbuatannya condition sine qua non menimbulkan keru-gian.

b. Adequate Veroorzaking

Menurut teori ini, si pelaku hanya bertanggung gugat atas kerugian yang merupakan akibat daripada perbuatan melanggar hukum yang secara layak dapat diperkirakan timbul. (Munir Fuady, 2008:162)

Kreditur pada saat tidak melakukan pencoretan pencatatan Jaminan Fidusia setelah hutang dari debitur dilunasi adalah bertentangan dengan kewajiban hukum dari kreditur sebagaimana ditentukan dalam Pasal 25 ayat (3) UU Jaminan Fidusia jo. Pasal 16 ayat (2) PP No. 21 Th. 2015, baik hal tersebut dilakukan karena kesengajaan ataupun karena kelalaian kreditur. Adanya kewajiban hukum dari kreditur dan adanya kerugian yang dialami oleh kreditur menjadi suatu hubungan kausalitas sehingga dengan kondisi tersebut debitur dapat mengajukan gugatan Perbuatan Melawan Hukum kepada kreditur.

Berdasarkan ketentuan Pasal 1365 Kitab Undang-Undang Hukum Perdata disebutkan bahwa Tiap perbuatan yang melanggar hukum dan membawa kerugian kepada orang lain, mewajibkan orang yang menimbulkan kerugian itu karena 
kesalahannya untuk menggantikan kerugian tersebut. Sehingga dengan demikian kreditur yang dinyatakan bersalah karena kelalaiannya melakukan pencoretan pencatatan Jaminan Fidusia bertanggung gugat untuk mengganti kerugian yang dialami oleh debitur.

\section{Kesimpulan}

Jaminan Fidusia merupakan perjanjian tambahan (accesoir) yang keberadaannya mengikuti perjanjian pokoknya. Dengan adanya pelunasan hutang yang menjadi perjanjian pokok maka mengakibatkan Jaminan Fidusia menjadi hapus. Pencoretan pencatatan Jaminan Fidusia setelah hapusnya Jaminan Fidusia karena adanya pelunasan hutang oleh debitur menjadi kewajiban dari kreditur. Kreditur yang karena kelalaiannya tidak melakukan pencoretan pencatatan Jaminan Fidusia dalam waktu 14 (empat belas) haris setelah adanya pelunasan hutang dari debitur dapat dikualifikasikan melakukan perbuatan melawan hukum dan bertanggung gugat untuk mengganti kerugian yang dialami oleh debitur jika debitur tidak dapat mendaftarkan kembali jaminan fidusia tersebut.

\section{Saran}

Perlu dilakukan perubahan terhadap UU Jaminan Fidusia yang memasukkan sanksi bagi kreditur yang lalai melakukan roya atas jaminan fidusia yang hutang pokoknya telah lunas
Budiono, Herlien, Kumpulan Tulisan Hukum Perdata di Bidang Kenotariatan, Citra Aditya Bakti, Bandung, 2008.

Fuady, Munir, Jaminan Fidusia, Citra Aditya Bakti, Bandung, 2000

Marzuki, Peter Mahmud, Penelitian Hukum, Kencana Prenada Media, Jakarta, 2010

Mertokusumo, Sudikno, Mengenal Hukum (Suatu Pengantar), Liberty, Yogyakarta, 1991

Rahardjo, Satijipto, Ilmu Hukum, Citra Aditya Bakti, Bandung, 2000

Satrio, J., Wanprestasi Menurut KUHPerdata, Doktrin, dan Yurisprudensi, Citra Aditya Bakti, Bandung, 2012

\section{Jurnal, Makalah dan Karya Ilmiah}

Diana, Farah, dkk.,, "Kajian Yuridis Pelaksanaan Penghapusan Jaminan Fidusia Secara Elektronik", Syiah Kuala Law Journal, Vol. 1, No.2 Agustus 2017

Sanusi, Ahmad, "Pendaftaran Jaminan Fidusia Dan Akibat Hukumnya", Jurnal Kebijakan Hukum, Volume 7 No 1 Maret 2013

Utomo, Hatta Isnaini Wahyu, "Hukum Jaminan", Bahan Ajar, Universitas Yos Sudarso, Surabaya, 2017, hal. 7

Widyari, Ida Ayu Made, "Akibat Hukum Pendaftaran Jaminan Fidusia Dalam Sistem Online", Tesis, Program Pasca Sarjana, Universitas Udayana, Denpasar, 2015

\section{Daftar Pustaka Buku-Buku}

